\title{
Effect of Controlled Atmospheres with Low Oxygen Levels on Extended Storage of Guava Fruit (Psidium guajava L. 'Pedro Sato')
}

\author{
Gustavo H.A. Teixeira ${ }^{1}$ and José F. Durigan \\ Universidade Estadual Paulista (UNESP), Faculdade de Ciências Agrárias \\ e Veterinárias, Departamento de Tecnologia, Via de acesso Prof. Paulo \\ Donato Castellane s/n, 14.884-900, Jaboticabal, SP, Brazil
}

Additional index words. respiration, ripening, softening, yellowing, pectin, shelf life

\begin{abstract}
The effects of controlled atmospheres (CAs) containing different levels of oxygen (air, 21, 15, 10, 5, and $1 \mathrm{kPa}$ ) were investigated during cold storage of 'Pedro Sato' guava at $12.5^{\circ} \mathrm{C}$ for 28 days. Atmospheres with lower $\mathrm{O}_{2}$ concentrations (1 and $\left.5 \mathrm{kPa}\right)$ significantly reduced respiratory rates and delayed the ripening process. This was confirmed by maintenance of fruit green color, higher total soluble, and reducing sugar contents. The control fruits and those stored in elevated oxygen concentrations (21 kPa) presented a climacteric peak. However, the peak was not observed for fruit maintained in atmospheres containing $1,5,10$, and $15 \mathrm{kPa} \mathrm{O}_{2}$. After transferring the fruits from $\mathrm{CA}$ to ambient storage, they ripened normally in just $2 \mathrm{~d}$ without presenting any low $\mathrm{O}_{2}$ injury symptoms, even from the lowest oxygen concentrations $\left(1\right.$ and $\left.5 \mathrm{kPa} \mathrm{O}_{2}\right)$. This supports the use of low-oxygen atmospheres for extended storage of 'Pedro Sato' guava fruit.
\end{abstract}

Although Brazil is the world's second largest guava producer (FAOSTAT, 2007), the exportation of this fruit was just $0.06 \%$ of the total crop production in 2003 (Rozane et al., 2003). The biggest obstacle for guava commercialization is its short shelf life. Guava is a climacteric fruit exhibiting respiratory and ethylene peaks, which causes the guava to rapidly achieve senescence (Nakasone and Paull, 1998). This makes the fruit inappropriate for consumption after a short period of time, e.g., guavas harvested at "breaker" stage ripened after just 24 to $48 \mathrm{~h}$ at ambient conditions (Akamine and Goo, 1979). Under optimum conditions $\left(10{ }^{\circ} \mathrm{C}\right)$, the storage potential ranges from 14 to $21 \mathrm{~d}$ (Paull, 1994).

The use of controlled atmospheres (CAs) has been recommended to extend the shelf life of many fruits (Kader, 1986). Although it has been successfully used for many tropical fruits, CA is not commonly used for storage of guava fruit. Atmospheres containing $2 \%$ to $5 \% \mathrm{O}_{2}$ and $0 \%$ to $1 \% \mathrm{CO}_{2}$ have been reported for guava stored at 5 to $15{ }^{\circ} \mathrm{C}$ (Kader, 2003). Others have suggested greater reductions in $\mathrm{O}_{2}$ levels associated with increases in $\mathrm{CO}_{2}$ with some evidence that the fruit do not respond well to $\mathrm{CO}_{2}$ levels higher than $10 \%$

Received for publication 5 Oct. 2009. Accepted for publication 19 Apr. 2010.

We thank FAPESP for sponsoring this research (Proc. 05/56159-1) and providing a postdoctoral scholarship (Proc. 05/56160-0) to the first author. We also thank José Maria Monteiro Sigrist for his special help during the setup of the flowboard system.

${ }^{1}$ To whom reprint requests should be addressed; e-mail teixeiragha@yahoo.com.br.
(Broughton and Leong, 1979). In fact, $\mathrm{CO}_{2}$ injury has been observed when guavas were stored at atmospheres containing $20 \% \mathrm{CO}_{2}$ after 3 weeks of storage at $12{ }^{\circ} \mathrm{C}$ (Castro and Sigrist, 1988).

Controlled atmospheres can delay ripening and decrease ethylene production in guavas without affecting respiration ( $\mathrm{Pal}$ and Buescher, 1993). On the other hand, Bleinroth (1996) reported a reduction in the respiration rates of guavas stored in CA storage $\left(3 \% \mathrm{O}_{2}\right.$ and $8 \%$ $\mathrm{CO}_{2}$ ) either for 5 or 6 weeks at $12{ }^{\circ} \mathrm{C}$ or for 3 weeks at room temperature compared with air storage without affecting the fruit quality. These differences in CA results might be related to different cultivars, because they present different tolerances to oxygen and carbon dioxide levels. For example, 'Lucknow-49', 'Allahabad Safeda', and 'Apple Color' guavas present better quality when stored for $30 \mathrm{~d}$ at $8{ }^{\circ} \mathrm{C}$ with atmospheres containing $5 \% \mathrm{O}_{2}+$ $2.5 \% \mathrm{CO}_{2}, 5 \% \mathrm{O}_{2}+5 \% \mathrm{CO}_{2}$, and $8 \% \mathrm{O}_{2}+5 \%$ $\mathrm{CO}_{2}$, respectively (Singh and Pal, 2008).

Although some CA storage recommendations for guava fruit can be found in the literature (Bleinroth, 1996; Castro and Sigrist, 1988; Kader, 2003; Singh and Pal, 2008), most of the information available concerns cultivars different from those grown in Brazil. The 'Pedro Sato' guava is the most important red pulp cultivar for fresh consumption in Brazil. The objective of this study was to determine the best oxygen concentration for extended cold storage of 'Pedro Sato' guava.

\section{Materials and Methods}

Fruit material. Freshly harvested guava (Psidium guajava L. cv. Pedro Sato) was obtained from a commercial orchard located at Vista Alegre do Alto (lat. $48^{\circ} 21^{\prime}$ W, long. $21^{\circ} 10^{\prime} \mathrm{S}$ ), São Paulo State, Brazil, at maturity stage 1 as proposed by Azzolini et al. (2004). At this stage, hue angle $\left({ }^{\circ} h\right)$ varied from 120 to 117. After harvest, fruits were transported to the Laboratório de Tecnologia dos Produtos Agrícolas of UNESP/FCAV, Jaboticabal Campus, São Paulo, Brazil.

Controlled atmosphere treatments. 'Pedro Sato' guava fruits, without any postharvest fungicide treatment, were placed in hermetic plastic containers $(20 \mathrm{~L})$ and stored at $12.5 \pm$ $0.8^{\circ} \mathrm{C}$ under a continuous humidified gas flow system [relative humidity $(\mathrm{RH}) \approx 95 \%$ ] of 100 $\mathrm{mL} \cdot \mathrm{min}^{-1}$. The flow rate and gas mixtures were established using a mixing board with capillary glasses (Claypool and Keefer, 1942). Compressed air provided the oxygen $\left(\mathrm{O}_{2}\right)$ source and nitrogen $\left(\mathrm{N}_{2}\right)$ was obtained from cylinders (White Martins Gases Industriais Ltda, Sertãozinho, Brazil). Both gases were mixed to obtain the following oxygen levels: $1,5,10,15$, and $21 \mathrm{kPa}$ balanced with nitrogen $\left(\mathrm{N}_{2}\right)$. The control fruit group was allowed to stay in the cold room but without any atmosphere modification $\left(21 \mathrm{kPa} \mathrm{O}_{2}, 0.08 \pm 0.01\right.$ $\mathrm{kPa} \mathrm{CO}$ and $66.6 \pm 4.9 \% \mathrm{RH})$. The oxygen $\left(\mathrm{O}_{2}\right)$ and carbon dioxide $\left(\mathrm{CO}_{2}\right)$ of the supply and the exhaust gas composition were monitored everyday using a Finningan 9001 gas chromatograph (Finningan Corporation, San Jose, CA). A single CA container containing 36 fruits represented an experimental unit, and it was replicated three times for each CA composition. Similarly, an uncovered plastic tray containing 36 fruits served as a control and was also replicated three times. The storage temperature was $12.5 \pm 0.8{ }^{\circ} \mathrm{C}(\mathrm{RH}$ $\approx 95 \%$ ) and fruit ripening occurred after they were withdrawn from CA storage to ambient conditions $\left(25.0 \pm 0.7^{\circ} \mathrm{C}, 95.4 \pm 4.3 \% \mathrm{RH}\right)$ at intervals of $14 \mathrm{~d}(0,14$, and $28 \mathrm{~d})$ to verify the effect of CA on ripening.

Respiration. At each 2-d interval during CA storage, the gas flow was discontinued for $1 \mathrm{~h}$ (static procedure) to determine the $\mathrm{CO}_{2}$ production of the fruits. This was done for each one of the oxygen concentrations and control (air) for the three replications. Initially $(0 \mathrm{~h})$ and after $1 \mathrm{~h}, 0.3-\mathrm{mL}$ gas samples from the container headspaces were analyzed for $\mathrm{CO}_{2}$ using a Finningan 9001 gas chromatograph (Finningan Corporation) equipped with a Porapack-N column and a thermal conductivity detector. Nitrogen, at a rate of $30 \mathrm{~mL} \cdot \mathrm{min}^{-1}$, was used as the carrier gas. Data were integrated using Borwin 1.20 software (JMBS Developpements, Le Fontanil, France).

Weight loss. The fruits in all treatments were initially weighed and the differences in weight (initial and after 14 and $28 \mathrm{~d}$ of cold storage) were calculated. This analysis was carried out immediately after the fruits were withdrawn from CA storage $(0,14$, and $28 \mathrm{~d})$ and when the fruit was considered ripe $(0+6$, $14+4$, and $28+2 \mathrm{~d}$ ).

Visual appearance. The visual appearance, based on the overall fruit quality (rots and dehydration), was assessed based on the following scale: 5 , excellent; 4 , very good; 3 , acceptable; 2 , bad; and 1 , extremely bad. 


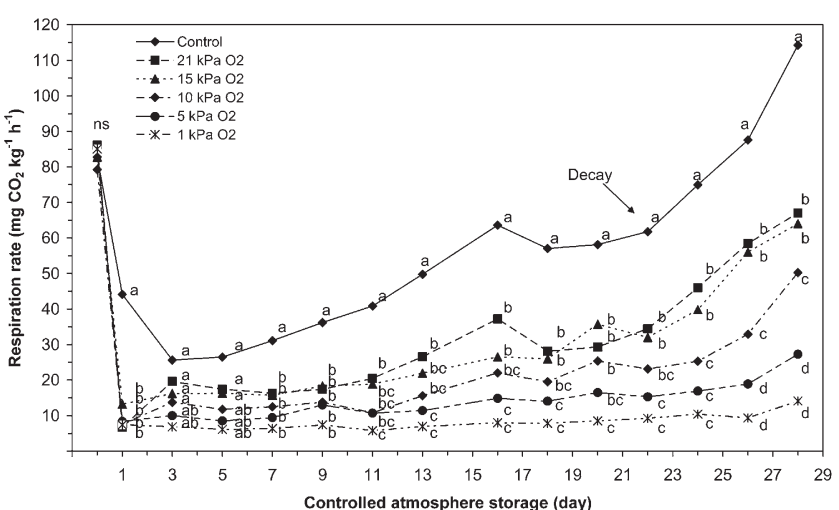

Fig. 1. Respiration rate $\left(\mathrm{mg} \mathrm{CO}_{2} \mathrm{~kg}^{-1} \cdot \mathrm{h}^{-1}\right)$ of 'Pedro Sato' guava fruit stored at $12.5^{\circ} \mathrm{C}$ for $28 \mathrm{~d}$ under controlled atmosphere with different levels of oxygen. Means within each day with the same letter are not significantly different (least significant difference, $P<0.05$ ). Ns, nonsignificant.

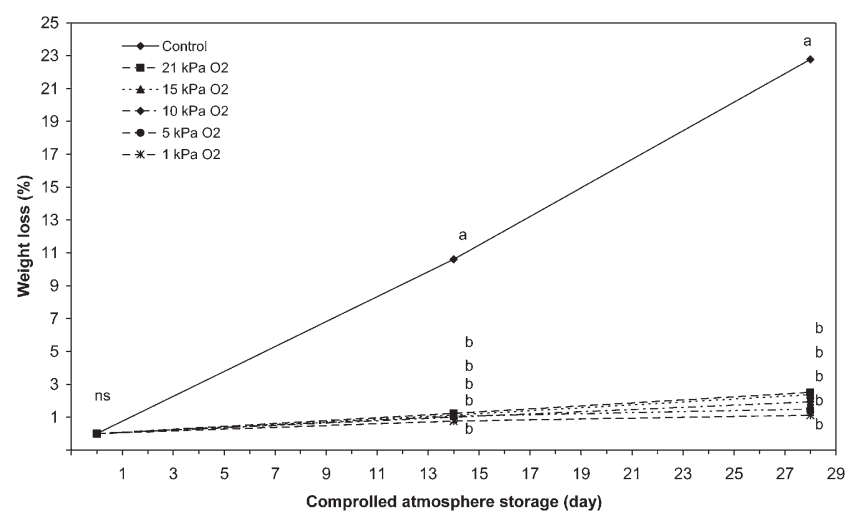

Fig. 2. Weight loss (\%) of 'Pedro Sato' guava fruit stored at $12.5^{\circ} \mathrm{C}$ for 28 $\mathrm{d}$ under controlled atmosphere with different levels of oxygen. Means within each day with the same letter are not significantly different (least significant difference, $P<0.05)$. NS, nonsignificant.

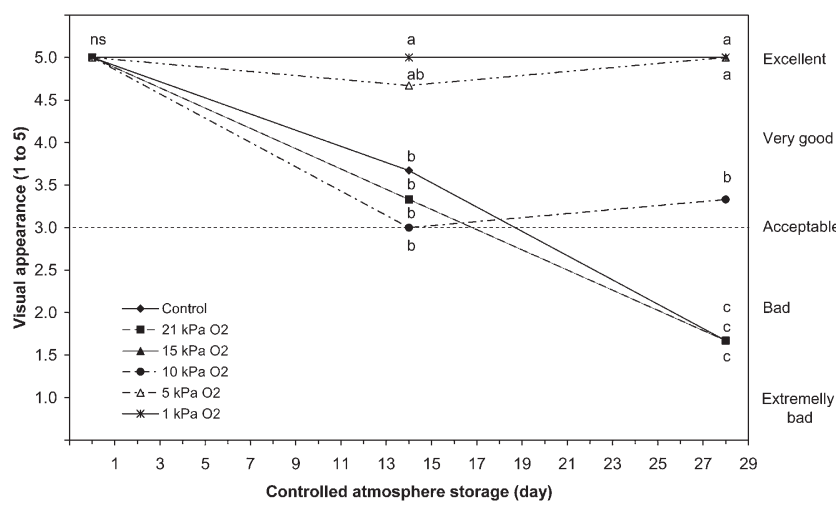

Fig. 3. Visual appearance (1 to 5) of 'Pedro Sato' guava fruit stored at 12.5 ${ }^{\circ} \mathrm{C}$ for $28 \mathrm{~d}$ under controlled atmosphere with different levels of oxygen. Means within each day with the same letter are not significantly different (least significant difference, $P<0.05$ ). NS, nonsignificant.

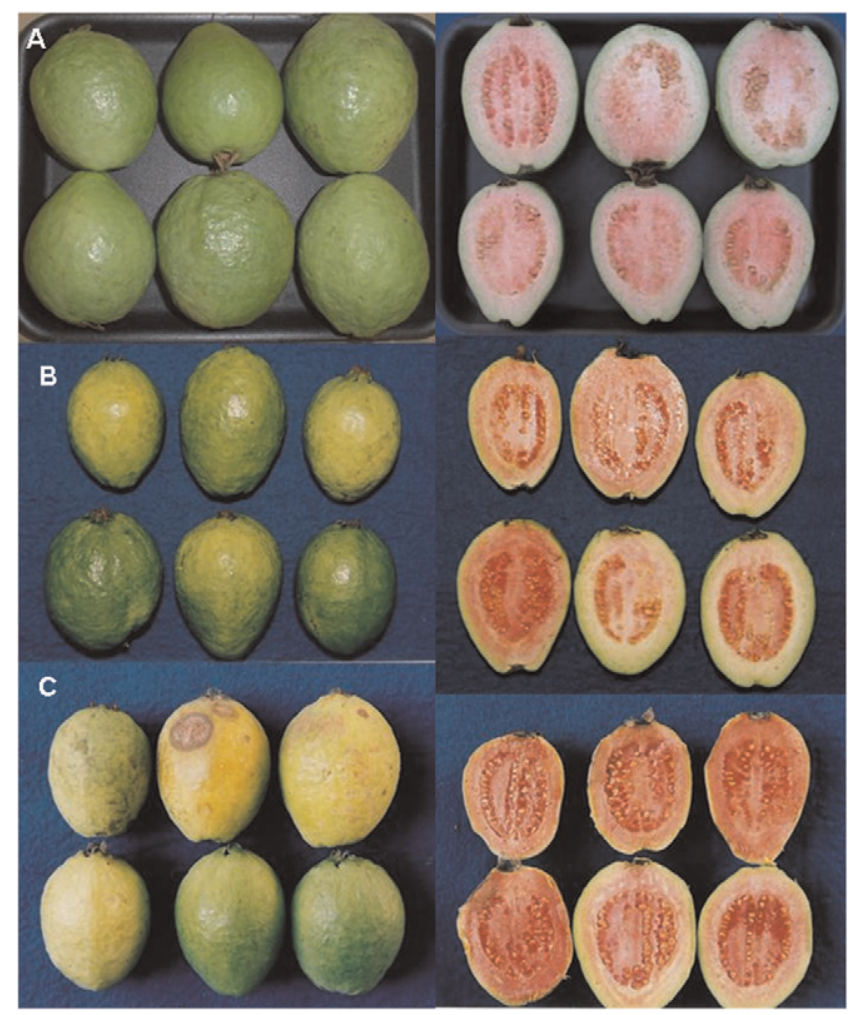

Fig. 4. Appearance of 'Pedro Sato' guava fruit storage under controlled atmosphere with different levels of oxygen at $12.5^{\circ} \mathrm{C}$ for $28 \mathrm{~d}$. (A) Day 0, (B) Day 14, and (C) Day 28. Top left, control); top center, $21 \mathrm{kPa}$; top right, $15 \mathrm{kPa}$; bottom left, $10 \mathrm{kPa}$; bottom center, $5 \mathrm{kPa}$; bottom right, 1 $\mathrm{kPa}$.

Chemical analysis. Immediately after the fruit was withdrawn from the CA condition $(0,14$, and $28 \mathrm{~d})$ and after ripening at ambient condition $(0+6$ and $14+4 d)$, guavas were homogenized in a blender and the homogenate was used to determine the soluble solids content (SSC), titratable acidity (TA), and $\mathrm{pH}$ (A.O.A.C., 1997; procedures 920.151, 93212, and 945-27, respectively). For determination of SSC, TA, and $\mathrm{pH}$, four fruits per replication were homogenized, and the homogenate was filtered through several layers of cheesecloth to obtain a clear juice. The SSC (\%) was recorded with a digital refractometer (Atago PR 101, Tokyo, Japan).
The TA was determined by titrating the fruit juice after dilution with distilled water against a $0.1 \mathrm{~N} \mathrm{NaOH}$ solution using phenolphthalein. The TA was expressed as a percentage of citric acid. The ratio of SSC/TA was also calculated. Ascorbic acid content was measured by a visual titration method using 2,6dichlorophenolindophenol dye (Strohecker and Henning, 1967). Fruit samples (5 g) were homogenized with $10 \mathrm{~mL}$ of $1 \%$ oxalic acid. The extract was made up to a volume of 100 $\mathrm{mL}$ and was filtered through Whatman No. 1 filter paper. Filtrates were titrated against 2,6dichlorophenolindophenol dye, which was standardized using an ascorbic acid standard. equatorial region was determined. 

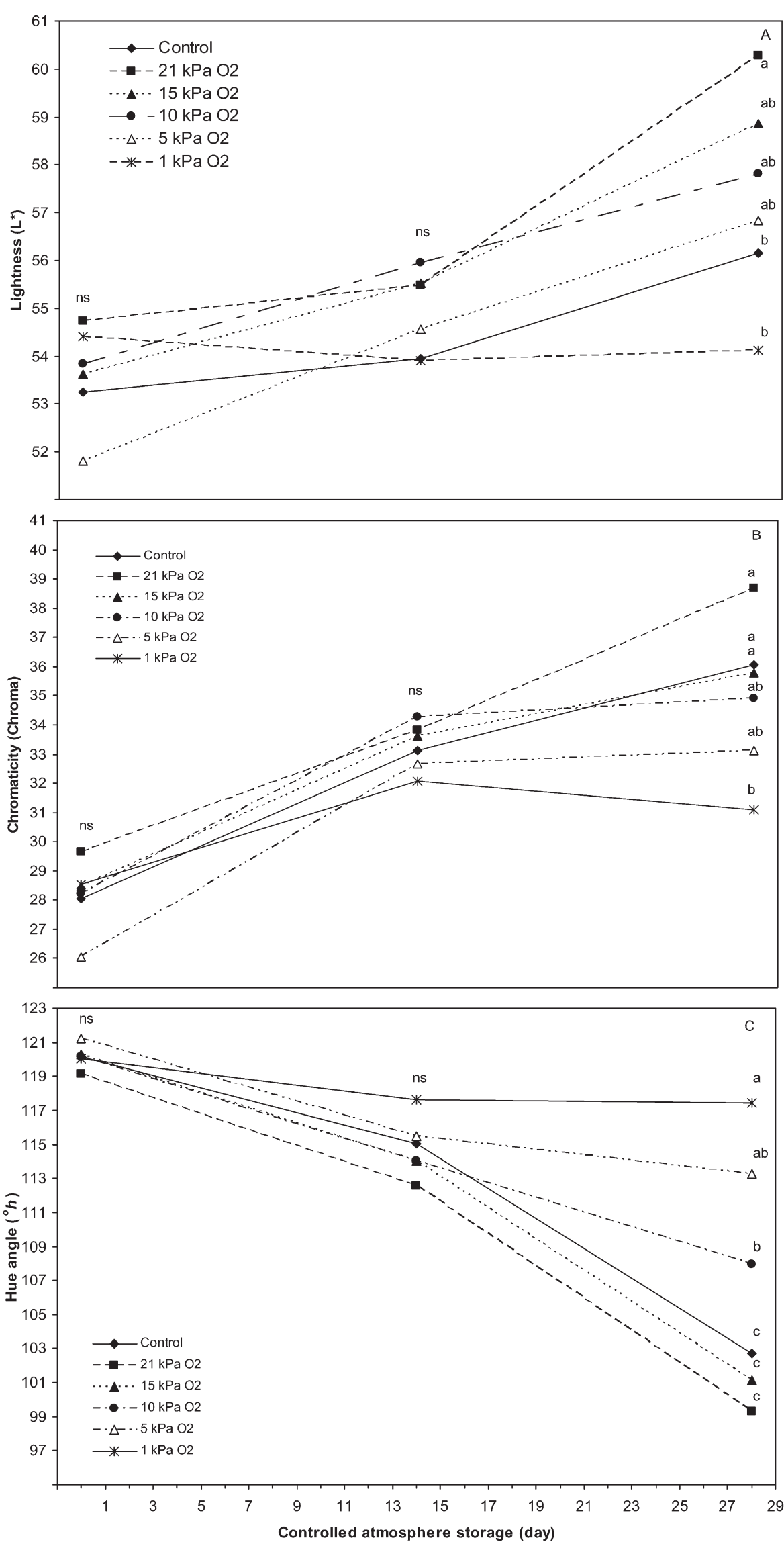

Fig. 5. (A) Lightness $\left(\mathrm{L}^{*}\right),(\mathbf{B})$ chromaticity (chroma), and $(\mathbf{C})$ hue angle $\left({ }^{\circ} h\right)$ of 'Pedro Sato' guava fruit stored at $12.5^{\circ} \mathrm{C}$ for $28 \mathrm{~d}$ under controlled atmosphere with different levels of oxygen. Means within each day with the same letter are not significantly different (least significant difference, $P<0.05$ ). NS, nonsignificant.
Ascorbic acid concentrations were expressed as $\mathrm{mg} / 100 \mathrm{~g}$ on a fresh weight basis.

The homogenates of all samples were rapidly frozen at $-20{ }^{\circ} \mathrm{C}$ and subsequently used to determine total soluble sugar (TSS), reducing sugar (RS), and total and soluble pectin. Frozen pulp samples $(5 \mathrm{~g})$ were homogenized with $80 \mathrm{~mL}$ of $80 \%$ ethanol for $1 \mathrm{~h}$ in a horizontal shaker. The extract was made up to a volume of $100 \mathrm{~mL}$ and filtered through Whatman No. 1 filter paper. From the filtered extract, $1 \mathrm{~mL}$ was transferred to a $100-\mathrm{mL}$ volumetric flask. Then the TSS was determined by its reaction with anthrone $(9,10$ dihydro-9-oxoanthracene) according a colorimetric assay proposed by Yemn and Willis (1954). In the same extract, the RS was determined using a 3,5-dinitrosalicilic acid colorimetric assay method (Miller, 1959). Total and soluble pectin were extracted according to the procedures described by McCready and McComb (1952), and they were colorimetrically determined using the carbazole assay method (Bitter and Muir, 1962).

Statistical analysis. The experiment was laid out in a completely randomized factorial design with two factors: the control and the oxygen level were the first factor, and the storage length (withdrawals at 0,14 , and $28 \mathrm{~d}$ ) was the second factor. The data of the fruit of all treatments immediately removed from the CA condition were subjected to analysis of variance, and the treatment means were compared using Tukey's test at a significance level of $P<0.05$. The data were analyzed using the PROC MIXED procedure of the Statistical Analysis System (SAS Institute Inc., 1996). Fruits transferred to ambient storage were also statistically analyzed according to a completely randomized design with six treatments (control and oxygen concentrations) and three replicates of six fruits $(0+6,14+4$, and $28+2$ d).

\section{Results and Discussion}

Respiration. Storage under the CA with different levels of oxygen significantly affected the respiration rate of 'Pedro Sato' guava fruit (Fig. 1). The fruit maintained under $\mathrm{CA}$ containing at 1 and $5 \mathrm{kPa} \mathrm{O}_{2}$ presented the lowest respiration rates throughout the cold storage period $(P<$ $0.05)$. There was also a gradual increase in respiration as oxygen levels were raised to 10,15 , and $21 \mathrm{kPa} \mathrm{O}_{2}$ and in the control fruit (Fig. 1). Since the beginning of storage, the control fruit presented the highest respiration rates compared with the other CA treatments $(P<0.05)$. These rates gradually increased until $16 \mathrm{~d}$ of storage, when there was a climacteric peak. After this peak, the rates decreased but then began to constantly increase after $22 \mathrm{~d}$ of storage as a result of the development of decay. In the samples stored under CA, and despite the reduction in respiration rates, there was also a delay, or even a total suppression, of the climacteric rise. A similar effect has also been reported earlier for guava (Bleinroth, 1996; Singh and Pal, 2008) and other fruits stored under CA such as cherimoya (Palma 


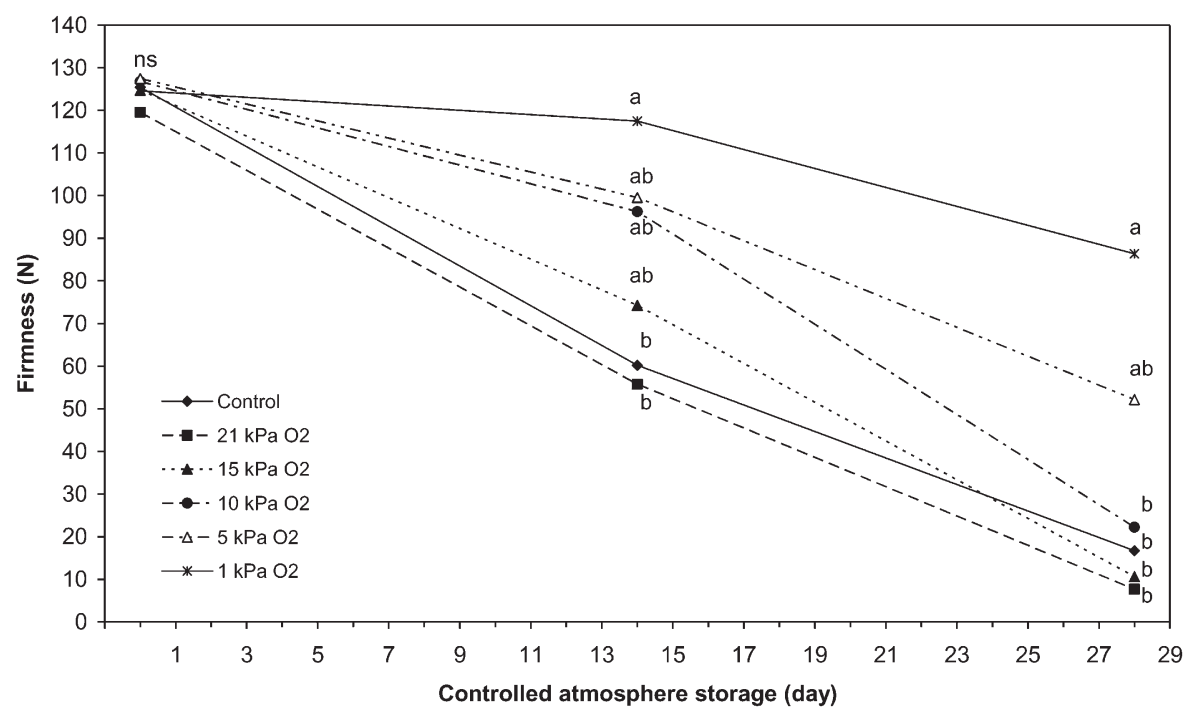

Fig. 6. Firmness (N) of 'Pedro Sato' guava fruit stored at $12.5^{\circ} \mathrm{C}$ for $28 \mathrm{~d}$ under controlled atmosphere with different levels of oxygen. Means within each day with the same letter are not significantly different (least significant difference, $P<0.05$ ). Ns, nonsignificant.

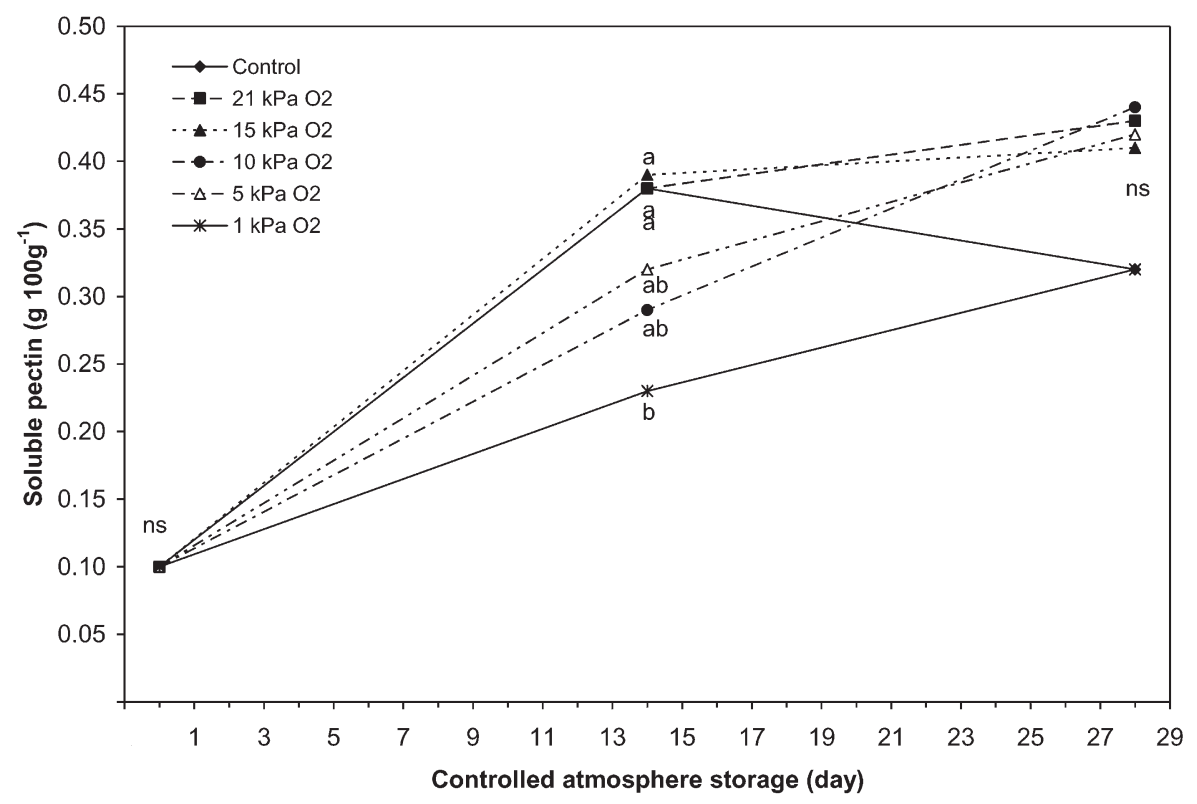

Fig. 7. Soluble pectin contents (g/100 g) of 'Pedro Sato' guava fruit stored at $12.5{ }^{\circ} \mathrm{C}$ for $28 \mathrm{~d}$ under controlled atmosphere with different levels of oxygen. Means within each day with the same letter are not significantly different (least significant difference, $P<0.05$ ). Ns, nonsignificant.

et al., 1993), apple (Saquet and Streif, 2002), and mango (Bender et al., 2000).

Although guava maintained under $\mathrm{CA}$ with $15 \mathrm{kPa} \mathrm{O}_{2}$ presented similar respiration rates as those stored in $21 \mathrm{kPa} \mathrm{O}_{2}$, they showed a lower respiratory peak compared with fruit stored in $21 \mathrm{kPa} \mathrm{O}_{2}$, and this peak occurred with a delay of $4 \mathrm{~d}$ (after $20 \mathrm{~d}$ ) compared with the control fruits (Fig. 1). Interestingly, the raise of respiration rate for guavas stored under atmosphere with $21 \mathrm{kPa} \mathrm{O}_{2}$ and control (air) occurred at the same day (16 d) but with different intensity. On the other hand, the fruits stored in 1,5 , and $10 \mathrm{kPa} \mathrm{O}_{2}$ had a completely suppressed climacteric rise. Those maintained under the $\mathrm{CA}$ with $1 \mathrm{kPa} \mathrm{O}_{2}$ also presented respiration rates that were quite constant for up to $28 \mathrm{~d}$ of cold
Table 1. Effect of controlled atmosphere with different levels of oxygen on titratable acidity (TA), ascorbic acid, and total pectin content of 'Pedro Sato' guava fruit stored at $12.5^{\circ} \mathrm{C}$ for $28 \mathrm{~d}$.

\begin{tabular}{|c|c|c|c|}
\hline Main effects & $\begin{array}{c}\mathrm{TA}^{\mathrm{y}} \\
(\mathrm{g} / 100 \mathrm{~g})\end{array}$ & $\begin{array}{c}\text { Ascorbic } \\
\text { acid } \\
(\mathrm{mg} / 100 \mathrm{~g})\end{array}$ & $\begin{array}{c}\text { Total } \\
\text { pectin } \\
(\mathrm{g} / 100 \mathrm{~g}\end{array}$ \\
\hline \multicolumn{4}{|c|}{ Atmospheres (A) } \\
\hline Control & 0.47 & $23.16 \mathrm{~b}$ & $1.28 \mathrm{a}$ \\
\hline $21 \mathrm{kPa} \mathrm{O}_{2}$ & 0.48 & $26.66 \mathrm{ab}$ & $1.26 \mathrm{ab}$ \\
\hline $15 \mathrm{kPaO} \mathrm{O}_{2}$ & 0.48 & $27.23 \mathrm{ab}$ & $1.24 \mathrm{ab}$ \\
\hline $10 \mathrm{kPaO}_{2}$ & 0.49 & $29.17 \mathrm{a}$ & $1.27 \mathrm{a}$ \\
\hline $5 \mathrm{kPa} \mathrm{O}$ & 0.49 & $27.34 \mathrm{ab}$ & $1.25 \mathrm{ab}$ \\
\hline $1 \mathrm{kPa} \mathrm{O}$ & 0.46 & $23.36 \mathrm{ab}$ & $1.19 \mathrm{~b}$ \\
\hline \multicolumn{4}{|l|}{ Storage $^{\mathrm{z}}(\mathrm{B})$} \\
\hline 0 & $0.46 \mathrm{~b}$ & $21.57 \mathrm{~b}$ & $1.27 \mathrm{a}$ \\
\hline 14 & $0.49 \mathrm{a}$ & $28.48 \mathrm{a}$ & $1.27 \mathrm{a}$ \\
\hline 28 & $0.48 \mathrm{a}$ & $28.41 \mathrm{a}$ & $1.21 \mathrm{~b}$ \\
\hline \multicolumn{4}{|l|}{ Interaction } \\
\hline $\mathrm{A} \times \mathrm{B}$ & NS & NS & NS \\
\hline CV (\%) & 5.13 & 15.88 & 4.41 \\
\hline
\end{tabular}

${ }^{\mathrm{z}}$ Storage in days.

${ }^{\mathrm{y}}$ Titratable acidity (grams of citric acid).

Means within the same column with the same letter are not significantly different (least significant difference, $P<0.05)$. Ns, interaction nonsignificant and $(* *)$ significant interaction $(P<0.01)$.

(Tucker, 1993) and for reducing the produce's sensibility to ethylene (Chitarra and Chitarra, 2005; Kader, 1995). Therefore, with the regulation of these metabolic pathways, guavas stored under CAs with low oxygen concentrations $(1$ and $5 \mathrm{kPa})$ showed a significant delay in ripening. It is noteworthy that the levels of $\mathrm{CO}_{2}$ did not influence respiration, because they were maintained as low as $0.08 \pm 0.01 \mathrm{kPa}$ $\mathrm{CO}_{2}$. The oxygen levels were also quite similar to the $5 \% \mathrm{O}_{2}$ atmospheres commonly recommended for other guava cultivars (Broughton and Leong, 1979; Kader, 2003; Singh and Pal, 2008).

Fruit quality. Independently of the oxygen concentration during CA storage, 'Pedro Sato' guava fruits lost less weight in CA conditions compared with the control fruits kept only in a cold room (Fig. 2). These data are consistent with the CA effects on moisture retention in guava (Singh and Pal, 2008). The control fruits showed significant increases in weight loss throughout storage, reaching values of $10.6 \%$ and $22.8 \%$ after 14 and $28 \mathrm{~d}$ of cold storage, respectively (Fig. 2). On average, fruits from the CA treatments lost only $2.5 \%$ of their original weights, mainly as a result of the moisture control provided by the humidified gas flow and the lower vapor pressure deficit values (VPD $=0.07 \mathrm{kPa}$ ), because the $\mathrm{RH}$ in the cold room was $\approx 66.6 \pm 4.9 \%$ and the VPD reached $0.48 \mathrm{kPa}$. According to Nakasone and Paull (1998), daily weight loss for guava is expected to be $0.3 \%$ per $0.1 \mathrm{kPa}$ in VPD, which was higher than that observed in the present study $(0.13 \%$ and $0.17 \%$ for guava stored in CA and air, respectively).

The high weight loss in the control fruits significantly affected their visual appearance, because they were considered withered and dehydrated after $28 \mathrm{~d}$ of cold storage (Figs. 3 and 4). Fruits stored under CAs with the lowest oxygen levels ( 1 and $5 \mathrm{kPaO}_{2}$ ) always received the best scores (excellent) compared with the 

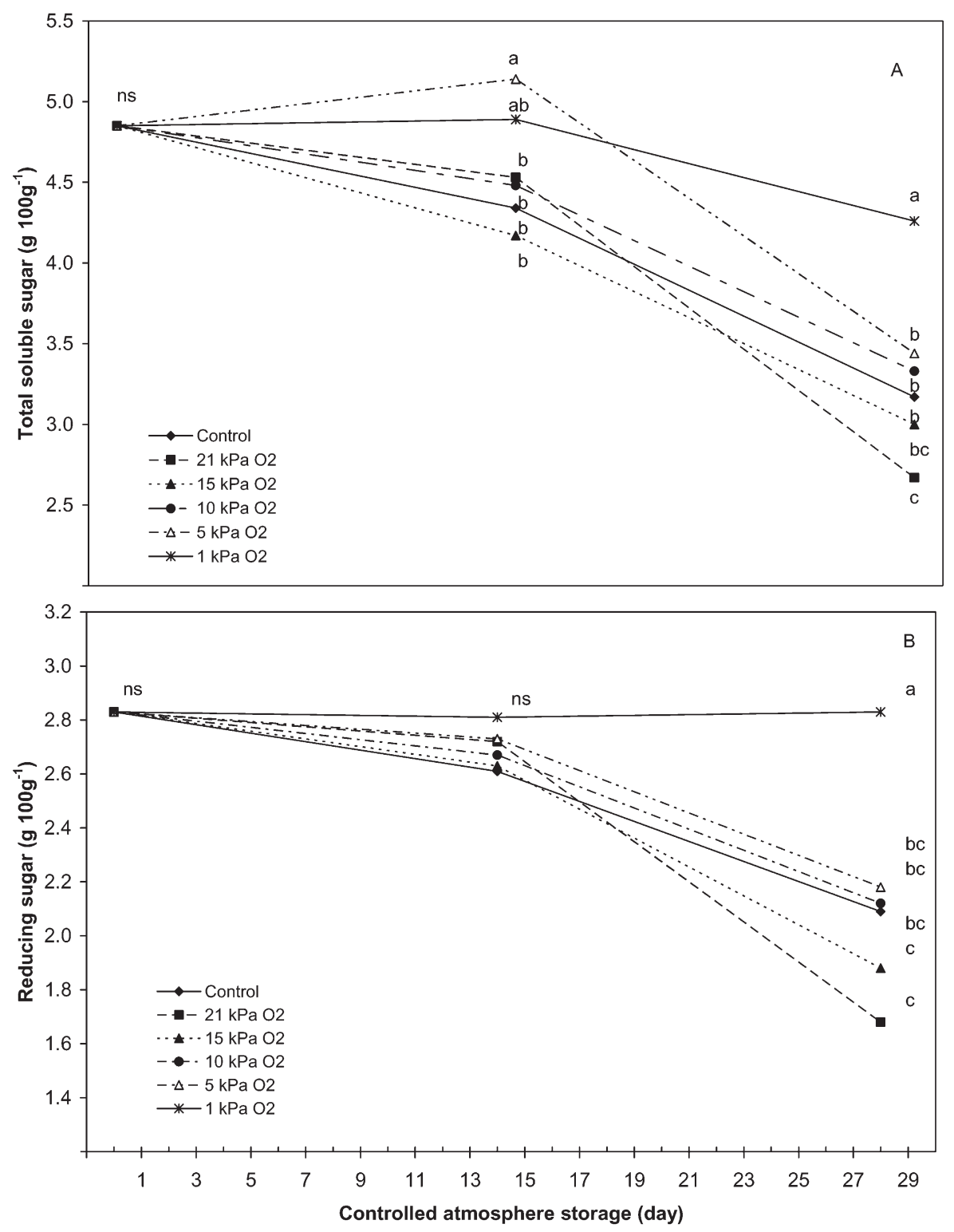

Fig. 8. (A) Total soluble sugar and (B) and reducing sugar contents (g/100 g) of 'Pedro Sato' guava fruit stored at $12.5^{\circ} \mathrm{C}$ for $28 \mathrm{~d}$ under controlled atmosphere with different levels of oxygen. Means within each day with the same letter are not significantly different (least significant difference, $P<0.05$ ). NS, nonsignificant.

fruits maintained in 10,15 , and $21 \mathrm{kPa}$. Turgor loss is largely a nonphysiological process associated with postharvest dehydration of the fruit and, as such, one can assume its commercial importance during storage (Tucker, 1993). In this sense, the elevation of RH in the environment of fruit stored under CA reduced moisture loss and provided better fruit quality during the cold storage of 'Pedro Sato' guavas compared with fruit stored under air.

The fruits stored in $1 \mathrm{kPa} \mathrm{O}_{2} \mathrm{CA}$ presented better color retention compared with those kept in atmospheres with higher oxygen levels, because the yellowing process, hue angle reduction, was partially suppressed $(P<0.05)$ (Fig. 5). This effect was more evident at the end of cold storage, when a gradual decrease in the hue angle was observed as the oxygen levels increased. A better maintenance of green color, higher hue angles $\left({ }^{\circ} h\right.$ greater than 113), occurred in fruit stored under the CAs with 1 and $5 \mathrm{kPa} \mathrm{O}_{2}$. This was possibly the result of the reduction of ethylene sensibility (Singh and Pal, 2008) and reduction of ethylene production through the inhibition of the ACC synthase and ACC oxidase (Chitarra and Chitarra, 2005; Kader, 1995). Because color change is dependent of ethylene action, once present, this hormone triggers the ripening process and, consequently, the many enzymes involved in the breakdown of chlorophyll molecules and the synthesis of carotenoid compounds (Tucker, 1993). As the skin color of the fruits stored in the 10,15 , and $21 \mathrm{kPa} \mathrm{O}_{2}$ CAs changed from green to greenish yellow, the $\mathrm{L}^{*}$ values increased and the fruit became brighter (Fig. 5). However, the fruits stored under the $\mathrm{CA}$ containing $1 \mathrm{kPa} \mathrm{O}_{2}$ did not present such modification, and the $\mathrm{L}^{*}$ values remained practically unchanged.

There was a decline in firmness in all treatments (Fig. 6). Nevertheless, the fruits maintained in $1 \mathrm{kPa} \mathrm{O}_{2}$ presented a consistent maximum retention of firmness. Guava firmness is initially related to its color (Bron et al., 2005). These authors studied firmness modifications on 'Pedro Sato' guava and observed an exponential relationship between skin color $\left({ }^{\circ} h\right)$ and chlorophyll fluorescence with maximum fluorescence and ${ }^{\circ} h$ presenting the highest correlations with firmness. Other authors have also reported high correlations between skin color and firmness in 'Pedro Sato' guavas (Azzolini et al., 2004). As mentioned, the fruits stored under CAs with 1 and $5 \mathrm{kPa}$ presented better green color retention. This could be one of the reasons for the maintenance of firmness in the fruits stored in such atmospheres.

On the other hand, textural modifications taking place during CA storage could also be related to the breakdown of the cell wall and starch molecules. The total pectin contents were significantly reduced during CA storage (Table 1) with a correspondent increase in pectin solubilization (Fig. 7). Although there were differences in solubilization over the $14 \mathrm{~d}$, the guavas kept in the $1 \mathrm{kPa} \mathrm{O}_{2} \mathrm{CA}$ presented the same content of soluble pectin after $28 \mathrm{~d}$ storage (Fig. 7). The other atmospheres $(5,10,15$, and $21 \mathrm{kPa} \mathrm{O})$ also were not sufficient to suppress the solubilization of these compounds. This is probably because they had a reduced effect on the key regulatory enzymes (e.g., polygalacturonase, pectinmethylesterase, and cellulase) that are responsible for the softening process of many fruits (Chitarra and Chitarra, 2005; Kader, 1995; Tucker, 1993). On the other hand, there was less carbohydrates mobilization related to TSS in the fruits maintained in the $1 \mathrm{kPa} \mathrm{O}_{2}$ (firmer) atmosphere. The guavas kept in this atmosphere presented greater TSS and RS retention in relation to the other oxygen levels and the control fruit throughout the storage (Fig. 8A-B). This was mainly attributable to lower respiration rates and other metabolic pathways.

The different CA compositions had a pronounced effect on the chemical attributes of guava fruit. The TA content increased throughout the cold storage with significant differences occurring from the second withdrawal (14 d). However, after this period, no significant differences were observed between the fruits from all treatments (Table 1). The SSC had a tendency to decrease during storage, but at the end of the CA storage, there was a clear distinction between two groups; the control fruits and those stored in 15 and $21 \mathrm{kPa}$ $\mathrm{O}_{2}$ presented the lowest contents and the fruit stored under the atmospheres with 1, 5, and 10 $\mathrm{kPa}$ had the highest SSC (Fig. 9A).

Ascorbic acid increased during CA storage, yet the oxygen levels had little effect on ascorbic acid content (Table 1). This might be a cultivar characteristic, because 'Pedro Sato' guavas have also showed increases in ascorbic acid content during ambient storage (Azzolini et al., 2004).

With the delayed ripening process observed for fruits stored at low oxygen levels (1 and $5 \mathrm{kPa}$ ), namely, reduced respiration 

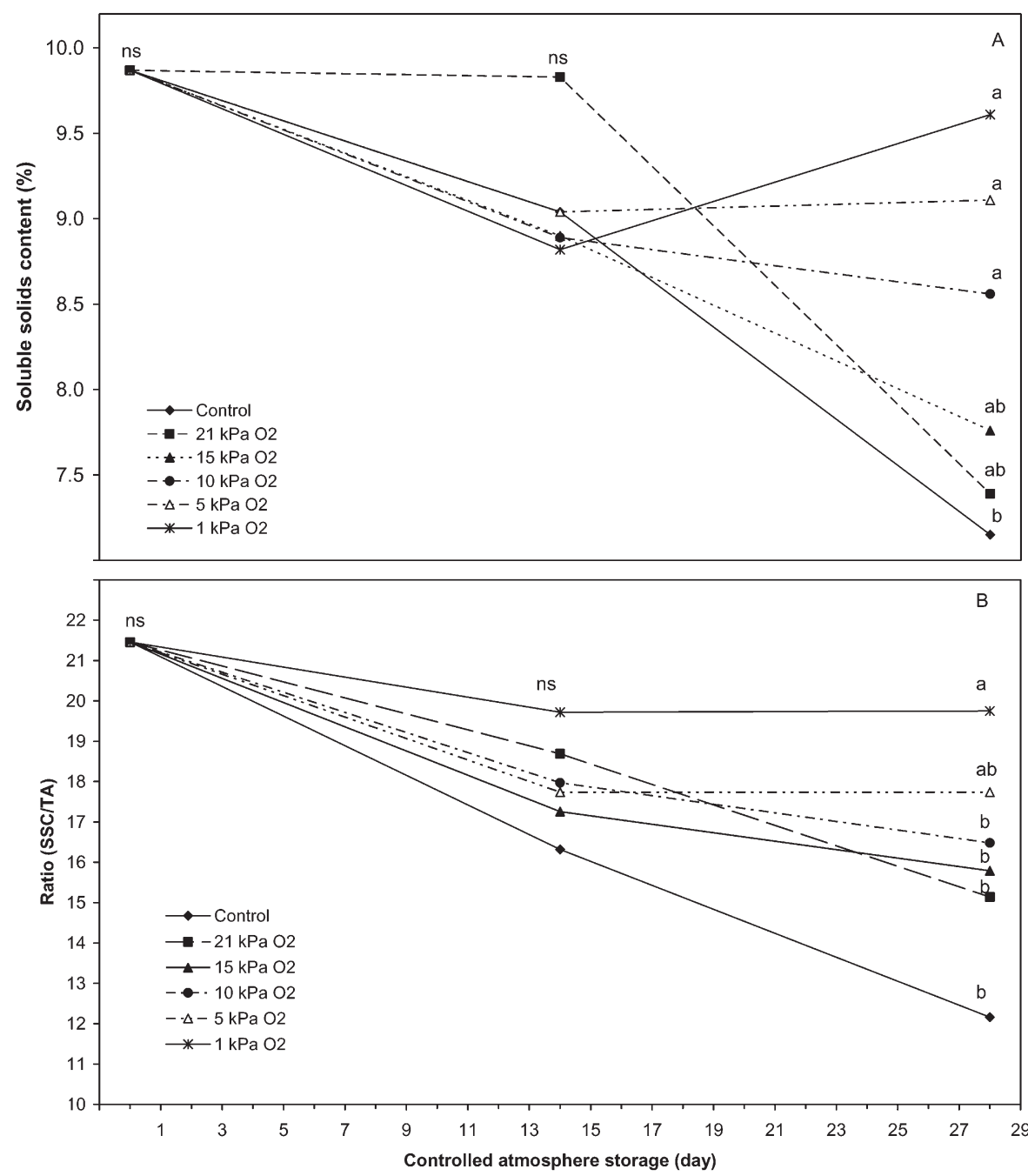

Fig. 9. (A) soluble solids content (SSC) and (B) ration SSC/AT of 'Pedro Sato' guava fruit stored at $12.5^{\circ} \mathrm{C}$ for $28 \mathrm{~d}$ under controlled atmosphere with different levels of oxygen. Means within each day with the same letter are not significantly different (least significant difference, $P<0.05$ ). Ns, nonsignificant.

rates and firmness retention, these fruits were not appropriate for consumption right after being removed from of CA, because they were still unripe. Their quality was quite similar to that of fruits newly harvested at the beginning of storage (Fig. 4). For this reason, they were transferred to ambient storage to verify whether the delay in ripening was intense enough to have hindered the fruit from ripening (Table 2).

From Table 2 it is evident that even the fruit previously maintained under atmospheres containing reduced oxygen levels (1 and $5 \mathrm{kPa}$ ) at $12.5^{\circ} \mathrm{C}$ for up to $28 \mathrm{~d}$ ripened normally after just $2 \mathrm{~d}$ in ambient storage

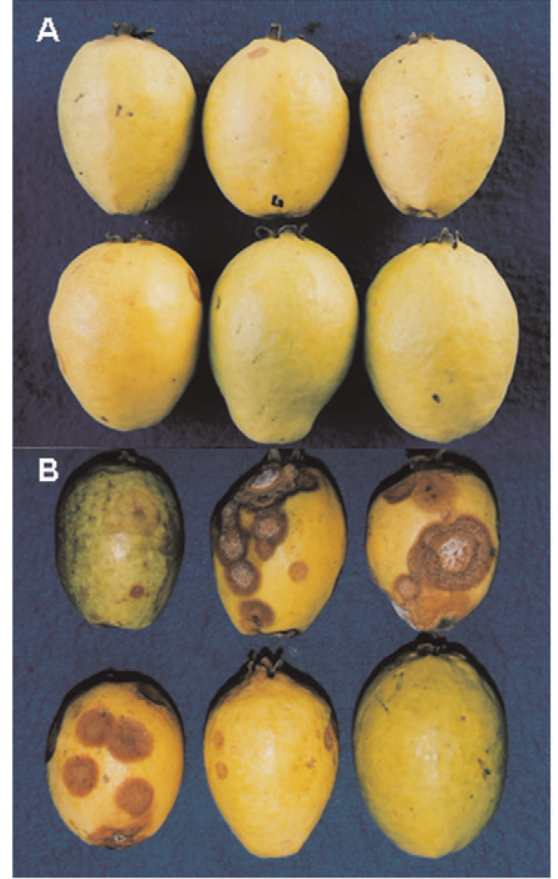

Fig. 10. Appearance of 'Pedro Sato' guava frui after storage under controlled atmosphere with different levels of oxygen at $12.5^{\circ} \mathrm{C}$ for $14 \mathrm{~d}$ (A) and $28 \mathrm{~d}$ (B) plus 4 and $2 \mathrm{~d}$ at ambient conditions $\left(25.2{ }^{\circ} \mathrm{C}\right)$, respectively. Top left, control; top center, $21 \mathrm{kPa}$; top right, $15 \mathrm{kPa}$; bottom left, $10 \mathrm{kPa}$; bottom center, $5 \mathrm{kPa}$; bottom right, $1 \mathrm{kPa}$.

(Fig. 10). Their quality was quite similar to those kept under the CAs with 15 and $21 \mathrm{kPa}$ $\mathrm{O}_{2}$ and the control fruits. These data, mainly color change and firmness reduction, are consistent with what was normally observed during 'Pedro Sato' guava ripening (Azzolini et al., 2004; Bron et al., 2005). Therefore, 'Pedro Sato' guava fruits can be stored in atmospheres containing between 1 and $5 \mathrm{kPa}$ $\mathrm{O}_{2}$ without compromising the ripening process or presenting any low $\mathrm{O}_{2}$ injury symptoms. This conclusion supports the use of these oxygen levels for 'Pedro Sato' guava fruits in extended storage. It is noteworthy that these levels are quite similar to the $5-\mathrm{kPa} \mathrm{O}_{2}$ levels recommended for other guava cultivars.

Table 2. Effect of controlled atmosphere with different levels of oxygen on initial and final weight loss (WL), color ( $\mathrm{L}^{*}$, chroma, hue angle), firmness, and visual appearance (1 to 5) of 'Pedro Sato' guava fruit after $28 \mathrm{~d}$ storage at $12.5^{\circ} \mathrm{C}$ plus $2 \mathrm{~d}$ at ambient conditions $\left(25.2^{\circ} \mathrm{C}\right)$.

\begin{tabular}{|c|c|c|c|c|c|c|c|c|c|c|c|c|}
\hline \multirow{2}{*}{ Main effects } & \multicolumn{6}{|c|}{ Initial $^{2}$} & \multicolumn{6}{|c|}{ Final $^{y}$} \\
\hline & $\begin{array}{l}\text { WL } \\
(\%)\end{array}$ & \multicolumn{3}{|c|}{ Color } & $\begin{array}{l}\text { Firmness } \\
(\mathrm{N})\end{array}$ & $\begin{array}{l}\text { Score } \\
\left(1 \text { to } 5^{x}\right)\end{array}$ & $\begin{array}{l}\text { WL } \\
(\%)\end{array}$ & \multicolumn{3}{|c|}{ Color } & $\begin{array}{c}\text { Firmness } \\
(\mathrm{N})\end{array}$ & $\begin{array}{l}\text { Score } \\
(1 \text { to } 5)\end{array}$ \\
\hline \multicolumn{13}{|l|}{ Atmospheres } \\
\hline $21 \mathrm{kPa} \mathrm{O}_{2}$ & $2.51 \mathrm{~b}$ & $60.26 \mathrm{a}$ & $38.71 \mathrm{a}$ & $99.29 \mathrm{~d}$ & $7.63 \mathrm{cb}$ & $1.33 \mathrm{c}$ & $16.51 \mathrm{ab}$ & $64.71 \mathrm{a}$ & $42.43 \mathrm{a}$ & 90.76 & $3.87 \mathrm{~b}$ & $1.00 \mathrm{~b}$ \\
\hline $15 \mathrm{kPa} \mathrm{O}_{2}$ & $2.37 \mathrm{~b}$ & $59.28 \mathrm{a}$ & $35.89 \mathrm{a}$ & $98.98 \mathrm{~d}$ & $10.57 \mathrm{~b}$ & $1.22 \mathrm{c}$ & $13.45 \mathrm{~b}$ & $65.51 \mathrm{a}$ & $41.07 \mathrm{a}$ & 89.64 & $2.23 \mathrm{~b}$ & $1.00 \mathrm{~b}$ \\
\hline $10 \mathrm{kPa} \mathrm{O}_{2}$ & $1.93 \mathrm{~b}$ & $58.33 \mathrm{ab}$ & $35.09 \mathrm{a}$ & $107.72 \mathrm{bc}$ & $22.18 \mathrm{~b}$ & $3.00 \mathrm{~b}$ & $11.91 \mathrm{~b}$ & $67.69 \mathrm{a}$ & $46.42 \mathrm{a}$ & 87.80 & $12.04 \mathrm{ab}$ & $1.00 \mathrm{~b}$ \\
\hline $5 \mathrm{kPa} \mathrm{O}$ & $1.50 \mathrm{~b}$ & $57.55 \mathrm{ab}$ & $33.57 \mathrm{ab}$ & $112.65 \mathrm{ab}$ & $52.14 \mathrm{~b}$ & $4.78 \mathrm{a}$ & $8.28 \mathrm{~b}$ & $67.57 \mathrm{a}$ & $48.09 \mathrm{a}$ & 90.20 & $16.40 \mathrm{a}$ & $1.67 \mathrm{~b}$ \\
\hline
\end{tabular}

${ }^{2}$ After withdraw from the cold room.

${ }^{\mathrm{y}} \mathrm{After} 2 \mathrm{~d}$ at ambient.

${ }^{\mathrm{x}} 1=$ extremely bad and $5=$ excellent.

Means within the same column with the same letter are not significantly different (least significant difference, $P<0.05$ ). 


\section{Literature Cited}

Akamine, E.K. and T. Goo. 1979. Respiration and ethylene production in fruits of species and cultivars of Psidium and Eugenia. J. Amer. Soc. Hort. Sci. 104:632-635.

A.O.A.C. 1997. Official methods of analysis of the Association of Official Analytical Chemists. 16th Ed. Patrícia Cuniff, Arlington, Washington, DC.

Azzolini, M., A.P. Jacomino, and I.U. Bron. 2004. Índices para avaliar qualidade pós-colheita de goiabas em diferentes estádios de maturação. Pesquisa Agropecu. Bras. 39:139-145.

Bender, R.J., J.K. Brecht, and S.A. Sargent. 2000. Mango tolerance to reduced oxygen levels in controlled atmosphere storage. J. Amer. Soc. Hort. Sci. 125:707-713.

Biale, J.B. 1964. Growth, maturation, and senescence in fruits. Science 146:880-888.

Bitter, T. and H.M. Muir. 1962. A modified uronic acid carbazole reaction. Anal. Biochem. 34: 330-334.

Bleinroth, E.W. 1996. Colheita e beneficiamento, p. 35. In: Neto, Á.G. (ed.). Goiaba para exportação: Procedimentos de colheita e pós-colheita. EMBRAPA-SPI, Brasília, Brazil.

Bron, I.U., R.V. Ribeiro, M. Azzolini, E.C. Machado, and A.P. Jacomino. 2005. Chlorophyll fluorescence emission and its relation to skin color and firmness during ripening of guava fruit. Fruit 60:25-32.

Broughton, W.J. and S.F. Leong. 1979. Maturation of Malaysian fruits. III. Storage conditions and ripening of guava (Psidium guajaba L. var. GU3 and GU4). Mardi Res. Bul. 7:12-26.

Castro, J.V. and J.M.M. Sigrist. 1988. Matéria prima, p. 121-140. In: Medina, L.C. (ed.). Goiaba:
Cultivo, matéria-prima, processamento e aspectos econômicos. ITAL, Campinas, Brazil.

Chitarra, M.I.F. and A.B. Chitarra. 2005. Póscolheita de frutos e hortaliças: Fisiologia e manuseio. 2nd Ed. Editora UFLA, Lavras, Brazil.

Claypool, L.L. and R.M. Keefer. 1942. A colorimetric method for $\mathrm{CO}_{2}$ determination in respiration studies. Proc. Amer. Soc. Hort. Sci. 40:177-176.

FAOSTAT. 2007. Food and Agriculture Organization of the United Nations, Statistics. 15 Dec. 2008. <http://faostat.fao.org>.

Kader, A.A. 1986. Biochemical and physiological basis for effects of controlled and modified atmospheres on fruits and vegetables. Food Chem. 40:99-100.

Kader, A.A. 1995. Regulation of fruit physiology by controlled/modified atmospheres. Acta Hort. 398:59-70.

Kader, A.A. 2003. A summary of CA requirements and recommendations for fruits other than apples and pears. Acta Hort. 600:737-740.

McCready, P.M. and E.A. McComb. 1952. Extraction and determination of total pectin materials. Anal. Chem. 24:1586-1588.

McGuire, R.G. 1992. Reporting of objective color measurements. HortScience 27:254-255.

Miller, G.L. 1959. Use of dinitrosalicylic acid reagent for determination of reducing sugars. Anal. Chem. 31:426-428.

Nakasone, H.K. and R.E. Paull. 1998. Tropical fruits. CAB International, Wallingford, UK.

Pal, R.K. and R.W. Buescher. 1993. Respiration and ethylene evolution of certain fruits and vegetables. J. Food Sci. Technol. 30:29-32.

Palma, T., D.W. Stanley, J.M. Aguilera, and J.P. Zoffoli. 1993. Respiratory behaviour of cheri- moya (Annona cherimola Mill.) under controlled atmosphere. HortScience 28:647-649.

Paull, R.E. 1994. Tropical fruit physiology and storage potential, p. 198-204. In: Champ, B.R., E. Highley, and G.I. Johnson (eds.). Postharvest handling of tropical fruits. ACIAR Proc. No. 50, Camberra, Australia.

Rozane, D.E., D.A. Oliveira, and V.S. Lírio. 2003. Importância econômica da cultura da goiabeira, p. 1-20. In: Rozane, D.E. and F.A.d'A. Couto (eds.). Cultura da goiabeira: Tecnologia e Mercado. UVF-EJA, Viçosa, Brazil.

Saquet, A.A. and J. Streif. 2002. Respiração e produção de etileno de maçãs armazenadas em diversas concentrações de oxigênio. Pesquisa Agropecu. Bras. 8:71-75.

SAS Institute Inc. 1996. SAS user's guide: Statistics. 8th Ed. SAS, Institute Inc, Cary, NC.

Singh, S.P. and R.K. Pal. 2008. Controlled atmosphere storage of guava (Psidium guajava $\mathrm{L}$.) fruit. Postharvest Biol. Technol. 47:296-306.

Strohecker, R.L. and H.M. Henning. 1967. Analisis de vitaminas: Métodos comprobados. Paz Montalvo, Madrid, Spain.

Teixeira, G.H.A., J.F. Durigan, L.O. Santos, F.O. Ogassavara, R.N. Martins, L.C. Cunha Júnior, and J.R. Donadon. 2007. Effect of controlled atmosphere with reducing levels of oxygen on incidence of postharvest diseases in guava (Psidium guajava L. cv. 'Pedro Sato'). Intl. Congr. Novel Approaches Control Postharvest Dis. Disorders. p. 59.

Tucker, G.A. 1993. Introduction, p. 2-51. In: Seymour, G.B., J.E. Taylor, and G.A. Tucker (eds.). Chapman \& Hall, Cambridge, UK.

Yemn, E.W. and A.J. Willis. 1954. The estimation of carbohydrate in plant extracts by anthrone. Biochem. J. 57:508-514. 